\title{
小特集 ホログラム記録の現状と実用化への道
}

\section{2-2. コリニア方式 \\ 2-2-2. 応用システム}

\author{
金子和 ${ }^{\dagger}$ \\ キーワードロ ホログラム, ホログラフィック, メタデータ, コリニア, コアキシャル, ストレージ
}

\section{1.まえがき}

コリニア方式のホログラム記録再生技術は，従来の光デ イスク技術との融合という点で優れた特徴を有している. 本稿では，光ディスクの記録再生技術を利用したメタデー 夕に焦点を当てて，コリニア方式ホログラム記録再生技術 の応用システムについて概説する. また, 現状の装置と将 来のシステム像, 実用化の可能性や課題を述べる.

\section{2.コリニア方式応用システムの特徵}

ホログラム記録の応用システムは，1)容量が大きい，(2) データ転送速度が高い, という点で光ディスクよりも優位 であり, (3)ランダムアクセス性が高い, (4)データ保存性 が高い, という点で磁気テープシステムよりも優位である. また，(5)記録定着後はホログラムが安定に保たれ，改ざ ん・誤追記されず，(6)物理的な情報の解析が難しく安全性 が高い, という点でホログラム記録特有の利点を持つ.こ れは二光束干渉方式においてもコリニア方式においても共 通の特徴である. したがって, ホログラム記録の主要な応 用システムについては本特集の二光束方式の章に譲る.

コリニア方式では, (7) システムがコンパクトで低価格に なりやすい，また，8光デイスクの製造設備を継承しやす く，事業化投資が小さくて済む. もう一つの特徵が9 データ記録層であり，次節に説明する。

\section{3.メタデータ記録層}

コリニア方式の特徵の一つはホログラム記録層に加え， メタデータ記録層の併載が可能なことである ${ }^{1)}$.

メタデータについては, 本誌 2007 年 2 月号に「最新メタデ 一夕事情」2) が特集されていて,「メ夕データとは, コンテ ンツを検索，特定，取得するための基本的な情報である.」 と説明されている.

コリニア方式では，主情報がホログラムとして記録され ている同一のディスク上に，さらに，メタデータが記録さ れる応用システムを構築することが可能である.

図1は，コリニア方式記録メディアの構造図である。記 †株式会社テクノコンサルティング

"Application System" by Yawara Kaneko (TechnoConsulting, Inc., Tokyo)
録メディアはプリフォーマット反射膜を施した基板上に波 長選択層，ホログラム記録層，蓋基板を積層することによ り形成される．光入射面からプリフォーマット反射膜に至 る深さは $1.2 \mathrm{~mm}$, プリフォーマットのトラック幅は $1.6 \mu \mathrm{m}$ に設計されており，CD-ROMに近い構造である.

コリニア方式の記録再生装置では，ホログラム記録再生 用に波長 $532 \mathrm{~nm}$ の緑色光源を用いる (第二世代以降は波長 405nmの青色半導体レーザ光源を用いる可能性が高い).

同時に波長 $650 \mathrm{~nm}$ の赤色光源が搭載されている. ホログ ラムの再生には, 再生参照光の光軸位置や入射角度など, 光学的に高い精度が要求される. 上下動や面ブレともなっ て回転するディスクに対してこの精度を見事に達成したの が赤色光とプリフォーマットを利用した従来光ディスクの サーボ技術である。

さらに，CD-RやDVD-Rで用いられる記録材料をプリフ オーマット上に配置し, 従来の光ディスクの記録機能をホ ログラム記録層の直下に持たせたのがメタデータ記録層で ある、メ夕デー夕記録層には, CD-Rと同等である $650 \mathrm{MB}$ の容量を期待できる.

\section{4 ．映画・放送情報記録システム}

映画や放送における映像情報は，現地での撮影，編集室

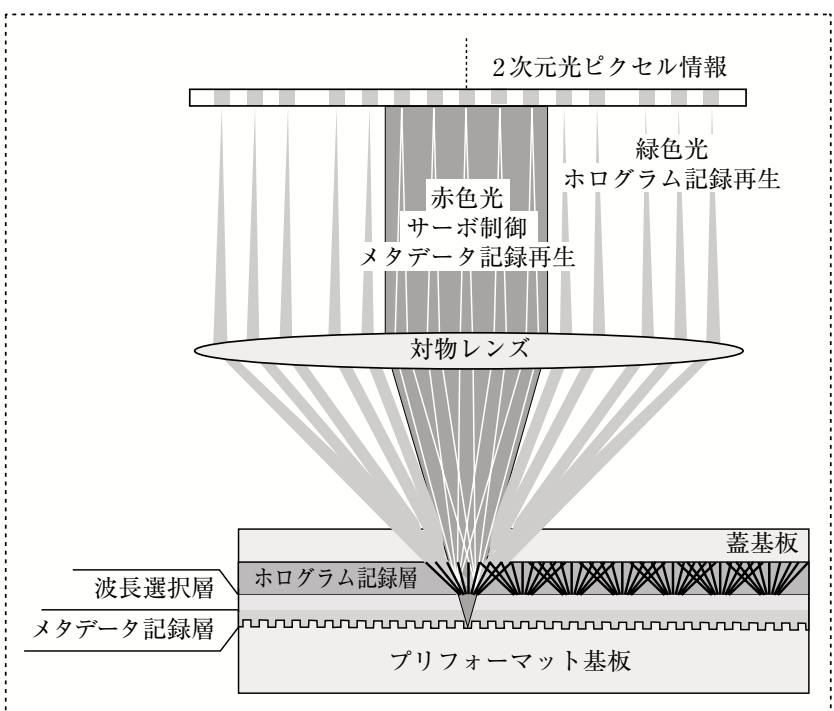

図 1 コリニア方式の記録再生概念とメディア構造図 
での作業, 倉庫での保管など, 現場から現場へ移動し, 担 当者から担当者へ引渡されていく．移動・引渡しに伴い, 各工程で映像情報に付加的な情報が追加生成され, 後工程 へと引継がれていく. 大量の映像情報をホログラム層に記 録できることと, 付加的な情報をメタデータ記録層に記録 できることから，コリニア方式は映画・放送の分野に利便 性の高い記録再生システムを提供できる.

例えば，撮影現場ではソースとなる映像がホログラム記 録層に録画された後, 撮影時間, 撮影場所, 撮影者, 撮影 対象, 撮影条件, 台本との対応関係, カット毎の頭出しア ドレス情報, 撮影者からのコメントなどがメタデータ記録 層に書込まれる，編集室ではまずメ夕データの情報を読出 し, 吟味してから, 効率よく大容量の映像情報を編集する ことができる.さらに編集作業後に, 編集作業日, 編集作 業者, 切出した映像情報のアドレス, 切出した映像情報の 用途先など，付加的情報をメタデータ記録層に追記する. メディア保管倉庫においては, 貸出し記録や, 貸出し先で 編集作業が発生した場合にはその編集情報がメタデータ記 録層に追記される。

ホログラム記録層はひとたび情報が記録され定着される と感光性を失い, 記録されたソース映像を損なうことがな い.メタデータ記録層を併載したコリニア方式の映画・放 送情報記録システムは, ソース映像を安全に保ちながら付 加的情報を加え, 1枚のディスク上で一元的かつ効率的な 映像情報の管理を可能とする.

\section{5. 防犯カメラシステム}

昨今, 安全管理のため, コンビニエンスストアや金融機 関の店舗や無人ATM機など, 町のいたるところに防犯力 メラが設置されるようになった. カメラの数が増加し, さ らに画質向上の要求から, 24 時間休みなく流れ込む映像情 報の量は膨大である。

一方, 画像認識の技術が進歩し, 撮影した動画映像から リアルタイムで特定の認識処理を行うシステムが商品化さ れている．2007年3月に東京ビッグサイトで開催されたセ キュリティショウでは, さまざまなリアルタイム認識処理 の例を見ることができた. 映像の中から顔部分を認識抽出 する処理, 抽出した顔をデータベースに照らして認証する 処理，データベースに照合されない場合に不審者として警 告する処理, 映像の中から人間を認識し, その認識情報か らフィードバック制御をかけてカメラをパン・ズームする 処理, 大勢の人が映っている映像の中から特定の人だけを 抽出する処理, さらにその人の動きをトラッキングする処 理, ある時点から定位置におかれたまま動かない不審物を 認識する処理, 太陽光などの変化を認識しカメラの感度や 絞りなどを調節する処理，などなどである.

防犯カメラから流れ込む膨大な映像情報をホログラム記 録層に記録し, リアルタイムに得られる認識情報, 処理情
報をメタデータ記録層に記録すれば，極めて効率のよい高 機能防犯カメラシステムを構築することができる.ここで 特筆すべきは，映像情報と認識・処理情報がデイスク上の 同一箇所に同時に記録されるので，再生時には映像情報と 認識・処理情報の間を行ったり来たりするトラック移動の 必要がない. 防犯カメラの映像情報からリアルタイムで得 られた認識・処理情報を, 映像情報再生と同時にリアル夕 イムで再生できる。また，メタデー夕記録層だけを再生し ながら，何かしらのイベントを検知したとき，例えば不審 者の警告を検知したときに，トラック移動なしにすぐにホ ログラム記録層の映像情報の再生に切替えることができる.

\section{6. データマイニングシステム}

情報をあるところに大量に集積させ, 後から必要な情報 を検索するデータマイニングシステムは, インターネット 検索など，もはや社会基盤としてなくてはならないもので ある.のちに検索されたときの検索情報を付加すると, も ともとの情報はより検索しやすい情報として進化する。そ こで収集・集積された情報をホログラム記録層に, 検索の たびに付加される検索情報をメタデータ記録層に記録する と, 進化性の高いデータマイニングシステムが構築される. 情報が検索される時には, 検索に使用したキーワード, 検索により新たに生成される情報へのアクセス, 検索日時, 検索者, などの検索情報が生成される. メ夕デー夕記録層 には検索のたびに検索情報を追記していくことができる. 次に検索される時には, メタデー夕記録層の検索情報も利 用することができる，検索すればするほど，検索時間が短 縮され, 検索精度が向上するデータマイニングシステムで ある。

\section{7. 実用化の可能性と課題}

実はコリニア方式のホログラム記録再生装置を市場で購入 することができる. パルステック工業が製造・販売してい るSHOT2000である (図2). 同社は, SHOT500, SHOT1000 とともにシリーズ化して，ホログラムメディア開発支援装 置を提供している．ホログラムメディア開発事業者が，原 材料から完成品に至るまで, 開発のそれぞれのフェイズに おいて, 試作品の評価・試験を行えるよう対応している.

SHOT2000は, 開発の中盤から終盤にかけて役立つ装置 で，ディスク形状に仕上げたホログラムメディアの記録再 生試験を目的としている。評価・試験項目, パラメータは パソコン $(\mathrm{PC})$ から入力し, 結果の数值データは $\mathrm{PC} に$ 出力 され, 解析しやすい形で表示される. 現在はホログラム記 録再生に波長 $532 \mathrm{~nm}$ の光源を用いている. 第二世代以降の システム商品化に参入を目指すメディア開発事業者のため には，波長 $405 \mathrm{~nm}$ の半導体レーザ光源を用いた記録再生試 験機の登場が待たれる.

SHOT2000を用いるとサーボプリフォーマット基板上に 


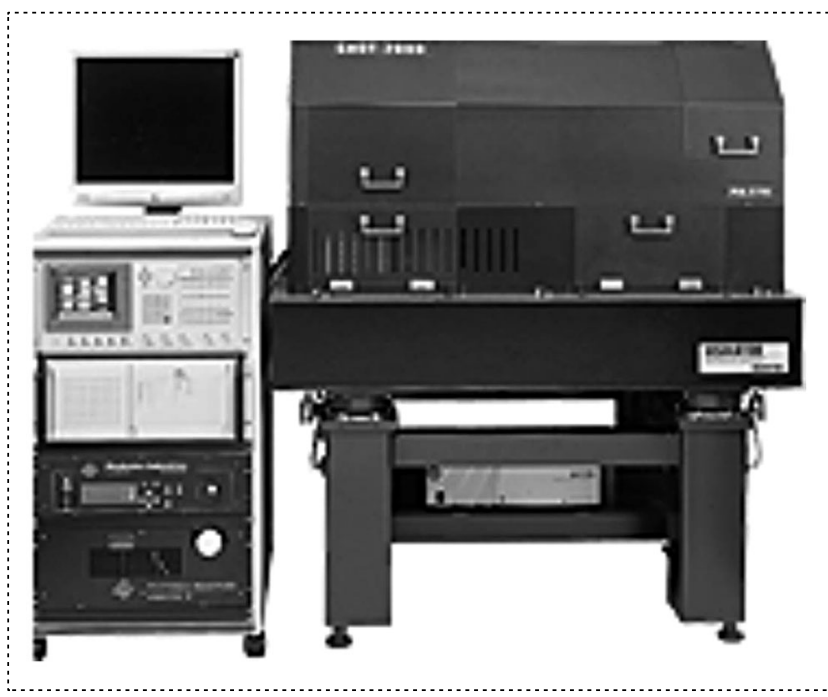

図2 コリニア方式の記録再生装置 SHOT2OOO (パルステック工業 (http://www.pulstec.co.jp/))

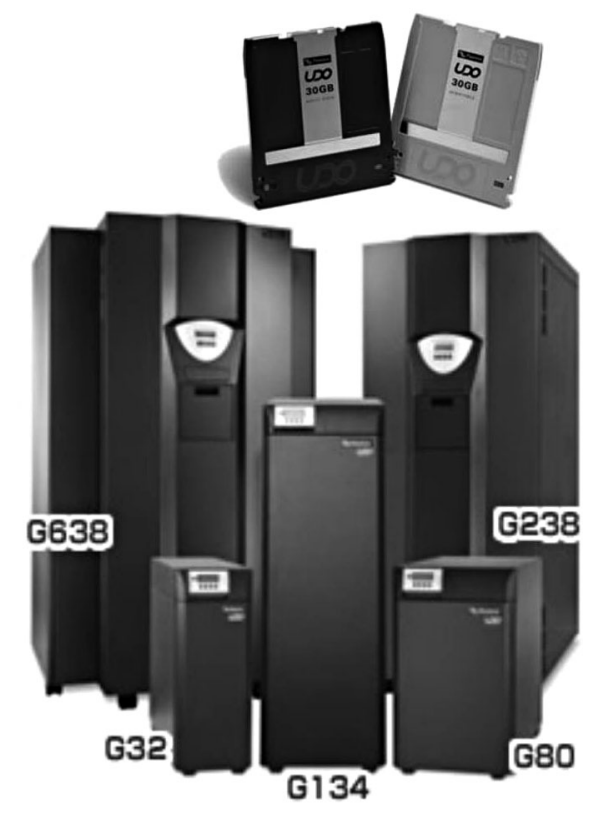

図3 応用システム像

(メモリーテック (http://www.memory-tech.co.jp/) のスターカイブ)

作製された記録メデイアを試験することもできるし，もう 少し前段階で記録材料を硝子ディスクで挟んだだけの簡単 な構造のホログラムメディアを評価することもできる。サ ーボプリフォーマットは, Ecmaインタナショナルにおい て技術的部分で標準規格化が成されており ${ }^{3)}$, SHOT2000 は，同標準規格に規定されるリファレンスドライブの機能 を備えたコリニア方式のホログラム記録再生装置である.

将来に実用化されるべきホログラム記録再生装置は, こ のSHOT2000を小さく一体化したものと考えればよい。才 プトウェアは, 制御部を専用のハードウェアとソフトウェ アに作りこみ, 光学部分をコンパクトに設計して, 一体型 として動作する装置を開発した ${ }^{4)}$.

応用システム像は，メモリーテックのスターカイブ(図3)
に似たものと考えてよい。これは光ディスク技術とロボテ イクス技術を駆使したUDO（ウルトラデンシティオプチカ ル (光デイスク))の世界最高性能のライブラリーシステム である. ホログラム記録メディアのカートリッジケースは, このシステムを継承できるよう, UDOと同一外形寸法に設 計されている.

実用化の鍵となるのは, 期待される記録容量・転送速度 の達成, 装置互換性・メディア信頼性の実証, 主要部品・ システム全体の小型化・低価格化である，記録容量の増大 については, ソニーのグループによる研究開発が進んでお り，記録密度は現状で180Gbpi ${ }^{2} ， 2008$ 年には1Tbpi2に達っ する勢いである ${ }^{5}$ 。転送速度については1Gbpsを当面の目標 としている、メタデー夕記録層を併載したメデイアによる 記録再生実験の報告例はないが, 充分に成熟した光ディス ク技術を取込むわけであるから，実現の可能性は高い.

\section{8.むす び}

コリニア方式ホログラム記録再生の応用システムを，メ タデー夕記録層の利用を含めて概説した，映画・放送情報 記録システムでは, ホログラム記録層とメタデー夕記録層 が1枚のディスクに併載されていることが利点である。防 犯カメラシステムでは, ホログラム記録層とメタデータ記 録層で同時に記録再生できることが利点である。データマ イニングシステムでは, メタデー夕記録層にあとから検索 情報を追記していけることが利点である。これまでの発展 を数十年来継続され，支えられた先人の功績に敬意を表す るとともに，魅力的な機能を持つこの技術が応用システム として実用化され，社会に役立つことを望んでやまない．

本稿執筆にあたりご協力いただいたオプトウェアの堀米 氏, パルステックの遠藤氏, 加藤氏, メモリーテックの高 谷氏, ソニーの福本氏に感謝する.

(2007年4月 4 日受付)

\section{[文 献]}

1) X. Tan, H. Horimai, T. Shimura, S. Ichimura, R. Fujimura and K. Kuroda: "Collinear Technology for Holographic Versatile Disc (HVD) System", Proceedings of SPIE, 6343 (Sep. 2006)

2) “小特集：最新メタデータ事情”, 映情学誌, 61, 2, pp.127-161 (2007)

3) http://www.ecma-international.org/memento/TC44.htm

4) 山本威一郎：“国際標準規格をめざして世界に挑戦する日本の先端技 術”, JST News, 3, 11, pp.4-7 (Feb. 2007)

5）福本 敦：“ホログラム光メモリーの現状”, ホログラフィックディ スプレイ研究会会報，27，1，pp.18-22（Mar. 2007）

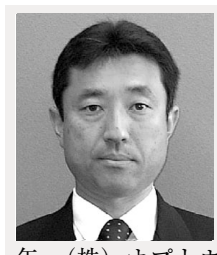
釛子和驾 1986 年, 上智大学院理工学研究科電 気電子工学専攻博士前期過程（修士課程）修了. 1986 年〜1988年, キャノン（株）入社. 1988年〜1994年 上智大学理工学部電気電子工学科助手. 1994年 1999 年, ヒューレットパッカード日本研究所. 1999年〜 2003年，アジレントテクノロジー (株). 2003年〜2006 年, (株) オプトウェア. 2006年, (株) テクノコンサルティング設立, 代 表取締役, 豊橋技術科学大学客員教授. 工学博士. 